\title{
The prevalence, risk factors, and prognostic value of venous thromboembolism in ovarian cancer patients receiving chemotherapy: a systematic review and meta-analysis
}

\author{
$\mathrm{Lu} \mathrm{Ye}^{1 \dagger}, \mathrm{Li} \mathrm{Cai}^{2+}$, Yonghui Fu ${ }^{3 \dagger}$, Debao Zhuang ${ }^{1}$, Xiaoging $\mathrm{Hu}^{2^{*}}$ and Youkun Jie ${ }^{1^{*}}$
}

\begin{abstract}
Background: Venous thromboembolism (VTE) in ovarian cancer (OC) patients has been widely investigated, but our knowledge on the role of VTE in OC patients receiving chemotherapy is limited. The aim of our study was to investigate the prevalence, risk factors, and prognostic value of chemotherapy-associated VTE in OC.

Methods: Three databases (PubMed, Embase, and the Cochrane Library) were systematically searched from inception to October 14, 2020. The primary outcome was the prevalence of VTE in OC patients receiving chemotherapy. The risk factors and prognostic value of VTE were the secondary outcomes. The pooled prevalence of VTE was estimated using the generic inverse-variance method. The statistical heterogeneity was evaluated with Cochran's $Q$ test and $P^{2}$ statistic. Funnel plot, Begg's test, and Egger's test were used to assess the potential publication bias in the meta-analysis.
\end{abstract}

Results: A total of eleven observational studies with 4759 OC patients were included. The pooled prevalence of VTE was $9 \%(95 \% \mathrm{Cl}, 0.06-0.12)$ in OC patients receiving chemotherapy. The results of subgroup analysis and sensitivity analysis were basically consistent with the overall pooled estimate. Multiple significant risk factors associated with VTE were also identified including advanced age, D-dimer $>0.5 \mathrm{mg} / \mathrm{mL}$, and tumor diameter $>10 \mathrm{~cm}$. Only two included studies reported the prognostic value of VTE in OC patients receiving chemotherapy, but with inconsistent results. Funnel plot showed that there existed potential publication bias, which was further verified by statistical test, but the results of the trim-and-fill method showed the pooled estimate kept stable after adding two "missing" studies.

\footnotetext{
* Correspondence: clez123@163.com; blackwhite121@163.com

${ }^{+} \mathrm{Lu}$ Ye, Li Cai and Yonghui Fu contributed equally to this work.

${ }^{2}$ Department of Oncology, Jiangxi Maternal and Child Health Hospital, Nanchang 330006, Jiangxi, China

'Department of Pathology, Jiangxi Maternal and Child Health Hospital, Nanchang 330006, Jiangxi, China

Full list of author information is available at the end of the article
}

(c) The Author(s). 2021 Open Access This article is licensed under a Creative Commons Attribution 4.0 International License, which permits use, sharing, adaptation, distribution and reproduction in any medium or format, as long as you give appropriate credit to the original author(s) and the source, provide a link to the Creative Commons licence, and indicate if changes were made. The images or other third party material in this article are included in the article's Creative Commons licence, unless indicated otherwise in a credit line to the material. If material is not included in the article's Creative Commons licence and your intended use is not permitted by statutory regulation or exceeds the permitted use, you will need to obtain permission directly from the copyright holder. To view a copy of this licence, visit http://creativecommons.org/licenses/by/4.0/ The Creative Commons Public Domain Dedication waiver (http://creativecommons.org/publicdomain/zero/1.0/) applies to the data made available in this article, unless otherwise stated in a credit line to the data. 
(Continued from previous page)

Conclusions: This current study revealed that the pooled prevalence of chemotherapy-related VTE in OC was approximately 9\% in OC patients. Risk factors for chemotherapy-related VTE were also identified which may contribute to targeting potentially preventative measures for VTE in OC.

Keywords: Venous thromboembolism, Ovarian cancer, Chemotherapy, Systematic review

\section{Introduction}

Venous thromboembolism (VTE), a known complication of malignancy, frequently develops in patients with ovarian cancer $(\mathrm{OC})$ with a relatively high incidence [1-3]. Moreover, thrombotic events are associated with increased morbidity, mortality, and impaired quality of life in patients with OC $[4,5]$. VTE may lead to increased hospital costs, which largely imposes additional burdens to the medical systems $[5,6]$. Numerous risk factors are identified to be linked to VTE in OC, including older age, low differentiated grade, D-dimer greater than $788 \mu \mathrm{g} / \mathrm{L}$, PT greater than $11.7 \mathrm{~s}$, and CA125 greater than $760 \mathrm{U} / \mathrm{mL}[7,8]$. In general, cytoreductive surgery together with postoperative chemotherapy is wellestablished management for OC, especially advanced OC [9-11]. It is well-known that surgery is an important inducer to the development of VTE, but increasing studies suggest that there also exists a positive correlation between chemotherapy and VTE in patients with malignancies $[12,13]$. Understandably, it seems to be very essential to clarify the prevalence, risk factors, and prognostic value of VTE in OC patients receiving chemotherapy, which may provide potential individualized guidance on the use of chemotherapy-associated VTE prophylaxis in OC.

Actually, accumulating evidence indicates that VTE is not rare in OC patients undergoing chemotherapy, but the prevalences are inconsistent across these published studies [14-17]. For instance, Salinaro and coworkers found that nearly $7.7 \%$ patients were diagnosed with VTE after receiving neoadjuvant chemotherapy for advanced OC [17]. Chavan et al. revealed that there was a $13.6 \%$ incidence of VTE in patients undergoing neoadjuvant chemotherapy for OC [15]. Furthermore, many studies found that some risk factors were deemed as significant predictors of chemotherapy-associated VTE prophylaxis in OC, including ascites, age 55 years and older, and tumor diameter greater than $10 \mathrm{~cm}[14,16]$. However, there were no studies to systematically summarize these identified risk factors and quantitatively explore the correlative dimension between these factors and chemotherapy-associated VTE in OC. Additionally, previous studies showed that VTE was an independent predictor of decreased survival outcomes in OC, but whether the same prognostic value of VTE also applies to $\mathrm{OC}$ patients undergoing chemotherapy is unclear.
Considering the above disputes and inconsistencies, we performed a systematic review and meta-analysis to comprehensively explore the prevalence, risk factors, and prognostic value of VTE in OC patients receiving chemotherapy, which may be conducive to provide potentially preventative measures for VTE.

\section{Methods}

This current meta-analysis was conducted in accordance with the guideline of the Meta-analysis of Observational Studies in Epidemiology checklist [18] and the Cochrane Handbook.

\section{Search strategy and study selection}

PubMed, Embase, and the Cochrane Library were systematically searched from the inception to October 14, 2020, using the search strategy including the terms for "chemotherapy," "thromboembolism," "ovarian cancer," and their variants. The detailed search strategy was shown in Additional file 1. Furthermore, we also checked the references of included studies and important reviews for any potential inclusion. Meanwhile, we searched unpublished studies through searching gray literatures including ClinicalTrials.gov, the ISRCTN metaregister of controlled trials, and World Health Organization trials page. We only included observational studies which explored the prevalence, risk factors, and prognostic value of VTE in OC patients receiving chemotherapy. Studies published in non-English language or published in non-full text (including abstracts) were excluded. For the same studies with different follow-ups, we merely included the one with the bigger sample size and longer duration. Endnote software was used to screen eligible studies according to the predefined inclusion criteria. Two reviewers ( $L u Y e$ and $L i$ $\mathrm{Cai}$ ) independently undertook search strategy and study selection, with inconsistence resolved by the chief reviewer (Youkun Jie).

\section{Data extraction}

A standardized data extraction form was used to extract the following data: year of publication; country or countries of origin; the demographic characteristics of OC patients; clinicopathological stage of OC; operative details; chemotherapy protocol; sample size; definition of VTE; the prevalence, risk factors, and prognostic value 
for VTE; confounders on multivariate analysis; and study design. Only adjusted RRs (relative risks) or ORs (odds ratios) with 95\% CIs (confidence intervals) on multivariate analysis were extracted.

\section{Methodological quality}

The quality of included studies was evaluated using the Newcastle-Ottawa Scale (NOS) score, which can be used to assess the quality of observational studies [19]. The score system contains three dimensions which include selection criteria of participants, comparability, exposure, and outcome. Every dimension was scored 3 points, and the maximum score of NOS is up to 9 [19].

\section{Statistical analysis}

The primary outcome was the prevalence of VTE in OC patients receiving chemotherapy. The risk factors and prognostic value of VTE were the secondary outcomes. The pooled prevalence of VTE was estimated using the generic inverse-variance method described by DerSimonian and Laird [20]. The correlative dimension of risk factors with chemotherapy-related VTE was summarized as odds ratios (ORs) with $95 \%$ confidence intervals (CIs). Only ORs with $95 \%$ CIs on multivariate analysis were used for pooled analyses. The prognostic role of chemotherapy-associated VTE on the overall survival (OS), disease-free survival (DFS), and relapse-free survival (RFS) in OV was assessed using hazard ratios (HRs) with 95\% CIs. Only meta-analyses were performed when three or more included studies reported the same outcomes of interest; otherwise, qualitative systematic reviews for them were conducted. The statistical heterogeneity was evaluated with Cochran's $Q$ test and $I^{2}$ statistic $[21,22]$. Considering the substantial clinical heterogeneity within or between included studies, random-effect model was used for all the meta-analyses in the current study. To explore the potential sources of heterogeneity in the current meta-analysis, we conducted meta-regression analysis to investigate the roles of sample size, NOS score, and year of publication in statistical heterogeneity. Moreover, subgroup analyses based on OC stages, sample size, study quality, chemotherapy regimens, and others were performed. Also, we undertook influence analyses to clarify the influence of individual included studies on the overall pooled estimate through removing one study each time. Funnel plot, Begg's test, and Egger's test were used to assess the potential publication bias in the meta-analysis [23, 24]. If there existed significant publication bias, subsequent sensitivity analysis using the trim-and-fill method was used to find the possible "missing studies" and further explore the effect of "missing studies" on the pooled effect estimate $[25,26]$.

\section{Results}

\section{Study selection}

We performed an updated search on October 14, 2020. A total of 1170 items were obtained through initial literature search from three databases (PubMed, Embase, and the Cochrane Library). After removing duplicated items, the remaining 731 studies were further checked through screening relevant titles and abstracts. A total of 668 studies were identified to be ineligible to our pre-defined inclusion criteria. Subsequently, the remaining 63 studies underwent full-text checking, and 52 full-text articles met the exclusion criteria. Finally, 11 studies were included in the current meta-analysis (Fig. 1) [14-17, 27-33].

\section{Study characteristics}

Of all the included studies, six were performed in Europe, three in the USA, and two in China. All the studies were published between 2008 and 2020 with sample size ranging from 18 to 2743 . Also, the disease states of patients in included studies were different from each other. Of these, patients in four included studies had advanced OC, while patients in two included studies had recurrent OC. Furthermore, the chemotherapy regimens in all the included studies were also different from each other. As a whole, seven studies involved in adjuvant chemotherapy and six in neoadjuvant chemotherapy. The detailed baseline characteristics and chemotherapy regimens in included studies are shown in Tables 1 and 2. Additionally, we assessed the methodological quality of included studies using NOS score (Table 3). The whole NOS score of candidate studies ranged from 5 to 8 points. One study was scored 5 points, one 6 points, three 7 points, and six 8 points, which indicated the most of included studies were moderate to high quality.

\section{Prevalence of VTE}

All the included studies reported the number of VTE, and the pooled prevalence of VTE was 9\% (0.06-0.12) with substantial heterogeneity $\left(I^{2}=88.9 \%\right)$ (Fig. 2). In general, VTE events are defined as deep vein thrombus (DVT) and pulmonary embolus (PE). Accordingly, we also explored the prevalence of DVT and $\mathrm{PE}$ in $\mathrm{OC}$ patients receiving chemotherapy. Our results indicated that the pooled prevalence of DVT and PE was $7 \%(0.04-0.10)$ and $2 \%(0.01-0.02)$, respectively (Fig. 3). Considering the significant heterogeneity across included studies, the meta-regression analyses based on sample size, publication time, and NOS score were used to explore the potential sources of statistical heterogeneity. The meta-regression analyses revealed that sample size $(p=0.002)$, but not 


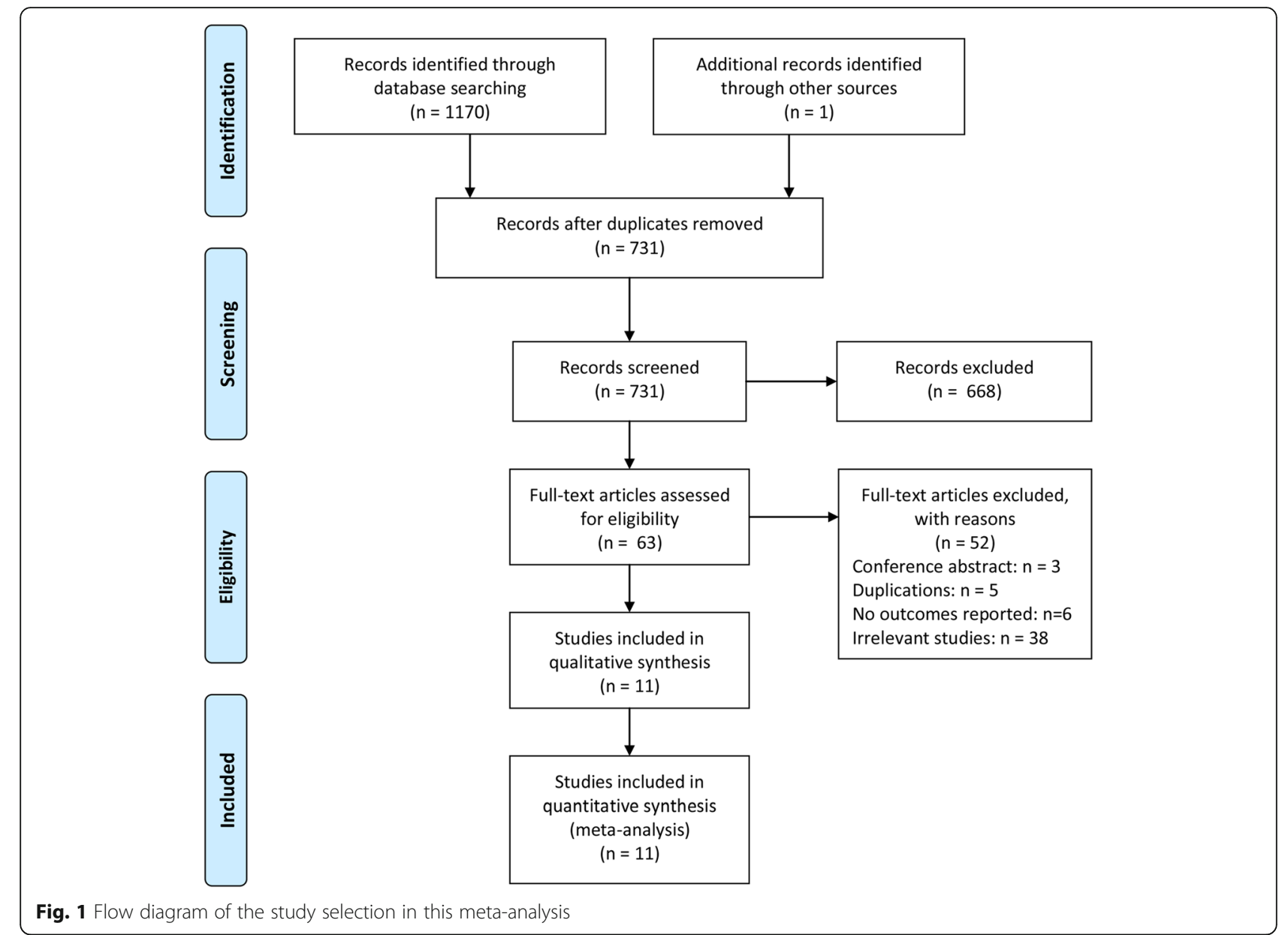

publication time $(p=0.207)$ and NOS score $(p=$ 0.817 ), may be the potential source of statistical heterogeneity. We also performed subgroup analyses based on different stratified standards including publication time, region, disease stages, operation type, sample size, VTE diagnostic criterion, study design, and NOS score. The pooled estimates of VTE in subgroups were basically consistent with the overall pooled effect except in those in publication time $\leq$ 2009 (0.06, 0.02-0.09), sample size > $500(0.05,0.01-$ 0.09), and Common Toxicity Criteria $(0.05,0.01-0.10)$ (Table 4). The pooled prevalences of VTE in patients receiving adjuvant and neoadjuvant chemotherapy were $8 \%(0.05-0.12)$ and $9 \%(0.07-0.11)$, respectively (Fig. 4). The results of influence analysis kept stable with ORs with CIs ranging from 0.086 (0.057-0.115) to 0.096 (0.061-0.13) (Fig. 5). We further evaluated whether there existed potential publication bias in the current meta-analysis. The funnel plot seemed to be asymmetrical, which was further verified by statistic tests (Begg's test: $p=0.755$; Egger's test: $p=0.003$; Fig. 6). Considering the significant publication bias, sensitivity analysis using the trim-and-fill method was used to explore the effect of "missing studies" on the pooled prevalence of VTE. The results showed that two studies were "missing" in the current metaanalysis. Interestingly, the new pooled estimate $(0.085$, $0.058-0.111)$ was basically consistent with the previous one (Fig. 6).

\section{Risk factors for VTE in OV patients receiving chemotherapy}

Only five studies reported multivariate or adjusted risk factors associated with VTE in OC patients receiving chemotherapy [14-16, 27, 28]. Owing to wide variations across these identified risk factors, we did not undertake meta-analyses for these variables quantitatively. We merely perform systematic reviews for them qualitatively (Table 5). Fotopoulou and colleagues found that age (35-81 years), BMI $<30 \mathrm{~kg} / \mathrm{m}^{2}$, and ascites were significant risk factors for VTE [27]. Mereu et al. revealed that BMI and monochemotherapy were significant predictors for VTE [28]. Zhang and coworkers investigated that age $>55$ 
Table 1 Characteristics of studies included in the meta-analysis

\begin{tabular}{|c|c|c|c|c|c|c|c|c|c|}
\hline $\begin{array}{l}\text { Author, } \\
\text { year }\end{array}$ & $\begin{array}{l}\text { Year } \\
\text { of } \\
\text { study }\end{array}$ & Country & $\begin{array}{l}\text { Disease } \\
\text { stage }\end{array}$ & $\begin{array}{l}\text { Operation } \\
\text { type }\end{array}$ & Chemotherapy type & $\begin{array}{l}\text { No. } \\
\text { of } \\
\text { VTEs }\end{array}$ & $\begin{array}{l}\text { No. of } \\
\text { participants }\end{array}$ & $\begin{array}{l}\text { VTE diagnostic } \\
\text { criterion }\end{array}$ & $\begin{array}{l}\text { Study } \\
\text { design }\end{array}$ \\
\hline $\begin{array}{l}\text { Fotopoulou } \\
\text { et al., } 2008 \\
\text { [27] }\end{array}$ & $\begin{array}{l}1995- \\
2002\end{array}$ & Germany & $\begin{array}{l}\text { Advanced } \\
\text { ovarian } \\
\text { cancer }\end{array}$ & $\begin{array}{l}\text { Debulking } \\
\text { surgery }\end{array}$ & Adjuvant chemotherapy & 76 & 2743 & $\begin{array}{l}\text { National Cancer } \\
\text { Institute Common } \\
\text { Toxicity Criteria }\end{array}$ & Case-control \\
\hline $\begin{array}{l}\text { Fotopoulou } \\
\text { et al., } 2009 \\
{[14]}\end{array}$ & $\begin{array}{l}1999- \\
2005\end{array}$ & Germany & $\begin{array}{l}\text { Recurrent } \\
\text { ovarian } \\
\text { cancer }\end{array}$ & $\begin{array}{l}\text { Radical } \\
\text { surgery }\end{array}$ & Adjuvant chemotherapy & 37 & 525 & $\begin{array}{l}\text { National Cancer } \\
\text { Institute Common } \\
\text { Toxicity Criteria }\end{array}$ & Case-control \\
\hline $\begin{array}{l}\text { Mereu et al., } \\
2009[28]\end{array}$ & $\begin{array}{l}1990- \\
2004\end{array}$ & Italy & $\begin{array}{l}\text { Ovarian } \\
\text { cancer }\end{array}$ & $\begin{array}{l}\text { Radical } \\
\text { surgery }\end{array}$ & Adjuvant chemotherapy & 16 & 203 & Self-definition & $\begin{array}{l}\text { Cross- } \\
\text { sectional } \\
\text { study }\end{array}$ \\
\hline $\begin{array}{l}\text { Guardiola } \\
\text { et al., } 2010 \\
\text { [29] }\end{array}$ & $\begin{array}{l}2004- \\
2007\end{array}$ & France & $\begin{array}{l}\text { Recurrent } \\
\text { ovarian } \\
\text { cancer }\end{array}$ & $\begin{array}{l}\text { Debulking } \\
\text { surgery }\end{array}$ & $\begin{array}{l}\text { Neoadjuvant } \\
\text { chemotherapy }\end{array}$ & 3 & 18 & $\begin{array}{l}\text { National Cancer } \\
\text { Institute Common } \\
\text { Toxicity Criteria }\end{array}$ & $\begin{array}{l}\text { Cross- } \\
\text { sectional } \\
\text { study }\end{array}$ \\
\hline $\begin{array}{l}\text { Saadeh } \\
\text { et al., } 2013 \\
\text { [30] }\end{array}$ & $\begin{array}{l}2006- \\
2010\end{array}$ & Ireland & $\begin{array}{l}\text { Ovarian } \\
\text { cancer }\end{array}$ & $\begin{array}{l}\text { Radical } \\
\text { surgery }\end{array}$ & $\begin{array}{l}\text { Neoadjuvant } \\
\text { chemotherapy or } \\
\text { adjuvant chemotherapy }\end{array}$ & 31 & 227 & Self-definition & Case-control \\
\hline $\begin{array}{l}\text { Pant et al., } \\
2014 \text { [31] }\end{array}$ & $\begin{array}{l}2008- \\
2011\end{array}$ & The USA & $\begin{array}{l}\text { Advanced } \\
\text { ovarian } \\
\text { cancer }\end{array}$ & $\begin{array}{l}\text { Radical } \\
\text { surgery }\end{array}$ & Adjuvant chemotherapy & 16 & 128 & Self-definition & Case-control \\
\hline $\begin{array}{l}\text { Chavan } \\
\text { et al., } 2017 \\
\text { [15] }\end{array}$ & $\begin{array}{l}2012- \\
2015\end{array}$ & China & $\begin{array}{l}\text { Ovarian } \\
\text { cancer }\end{array}$ & $\begin{array}{l}\text { Radical } \\
\text { surgery }\end{array}$ & $\begin{array}{l}\text { Neoadjuvant } \\
\text { chemotherapy or } \\
\text { adjuvant chemotherapy }\end{array}$ & 20 & 147 & Self-definition & $\begin{array}{l}\text { Retrospective } \\
\text { cohort }\end{array}$ \\
\hline $\begin{array}{l}\text { Greco et al., } \\
2017 \text { [32] }\end{array}$ & $\begin{array}{l}2009- \\
2014\end{array}$ & The USA & $\begin{array}{l}\text { Advanced } \\
\text { ovarian } \\
\text { cancer }\end{array}$ & $\begin{array}{l}\text { Debulking } \\
\text { surgery }\end{array}$ & $\begin{array}{l}\text { Neoadjuvant } \\
\text { chemotherapy }\end{array}$ & 12 & 111 & Self-definition & $\begin{array}{l}\text { Retrospective } \\
\text { cohort }\end{array}$ \\
\hline $\begin{array}{l}\text { Kuk et al., } \\
2017 \text { [33] }\end{array}$ & NA & Poland & $\begin{array}{l}\text { Advanced } \\
\text { ovarian } \\
\text { cancer }\end{array}$ & $\begin{array}{l}\text { Debulking } \\
\text { surgery }\end{array}$ & Adjuvant chemotherapy & 5 & 57 & Self-definition & Case-control \\
\hline $\begin{array}{l}\text { Zhang et al., } \\
2018 \text { [16] }\end{array}$ & $\begin{array}{l}2014- \\
2017\end{array}$ & China & $\begin{array}{l}\text { Ovarian } \\
\text { cancer }\end{array}$ & $\begin{array}{l}\text { Debulking } \\
\text { surgery }\end{array}$ & $\begin{array}{l}\text { Neoadjuvant } \\
\text { chemotherapy }\end{array}$ & 35 & 370 & Self-definition & Case-control \\
\hline $\begin{array}{l}\text { Salinaro } \\
\text { et al., } 2020 \\
{[17]}\end{array}$ & $\begin{array}{l}2000- \\
2013\end{array}$ & The USA & $\begin{array}{l}\text { Ovarian } \\
\text { cancer }\end{array}$ & $\begin{array}{l}\text { Debulking } \\
\text { surgery }\end{array}$ & $\begin{array}{l}\text { Neoadjuvant } \\
\text { chemotherapy }\end{array}$ & 16 & 230 & Self-definition & $\begin{array}{l}\text { Retrospective } \\
\text { cohort }\end{array}$ \\
\hline
\end{tabular}

VTE venous thromboembolism

years, PLT > $300109 / \mathrm{L}, \mathrm{D}$-dimer $>0.5 \mathrm{mg} / \mathrm{mL}$, and tumor diameter $>10 \mathrm{~cm}$ were significant risk factors for VTE. Of these, D-dimer $>0.5 \mathrm{mg} / \mathrm{mL}$ was the strongest predictor for VTE (OR 17.317; 95\% CI, 3.485-86.057) [16].

\section{Prognostic value of VTE in OC patients receiving chemotherapy}

Only two included studies reported the prognostic value of chemotherapy-associated VTE in OC patients [14, 27]. Fotopoulou et al. found that 1-year mortality in the VTE group was significantly higher than that in the nonVTE group [27]. Multivariate analysis indicated that neither PE nor DVT was associated with a higher OC recurrence [27]. Furthermore, another study revealed that VTE was not an independent prognostic factor for progression-free survival in OC patients receiving platinum-based first-line chemotherapy [14].

\section{Discussion}

The current meta-analysis based on 11 observational studies indicated that VTE was a relatively common complication in OC patients receiving chemotherapy. The systematic review for risk factors found that some risk factors were potential predictors for VTE including advanced age, D-dimer $>0.5 \mathrm{mg} / \mathrm{mL}$, and tumor diameter $>10 \mathrm{~cm}$.

Our findings revealed that the pooled prevalence of chemotherapy-related VTE in OC was approximately $9 \%$ in OC patients with substantial heterogeneity (88.9\%). Considering that significant heterogeneity may impair the evidence quality of the pooled estimate, the metaregressions based on publication time, sample size, and NOS score were performed to explore the potential sources of statistical heterogeneity. We found that sample size may be an important reason responsible for significant statistical heterogeneity. Consistently, subgroup analysis based on sample size showed that the pooled 
Table 2 Chemotherapy regimens of studies included in the meta-analysis

\begin{tabular}{|c|c|}
\hline Author, year & Chemotherapy regimens \\
\hline $\begin{array}{l}\text { Fotopoulou et al., } \\
2008 \text { [27] }\end{array}$ & Platinum/paclitaxel-based chemotherapy. \\
\hline $\begin{array}{l}\text { Fotopoulou et al., } \\
2009 \text { [14] }\end{array}$ & Platinum-based first-line chemotherapy. \\
\hline Mereu et al., 2009 [28] & $\begin{array}{l}\text { The first-line chemotherapy schedules were as follows: cysplatinum (CDDP } 50 \mathrm{mg} / \mathrm{mq} \text { weekly), cysplatinum + other drugs } \\
\text { (CDDP } 50 \mathrm{mg} / \mathrm{mq}+\text { cyclophosphamide } 600 \mathrm{mg} / \mathrm{mq} \text { T adriamycin } 45 \mathrm{mg} / \mathrm{mq} \text { every } 3 \text { Y4 weeks), carboplatin (JM8 AUC6 every } \\
3 Y 4 \text { weeks), and carboplatin + other drugs (JM8 AUC6 + paclitaxel } 175 \mathrm{Y} 225 \mathrm{mg} / \mathrm{mq} \text { every } 3 \text { weeks, JM8 AUC6 + epirubicin } \\
120 \mathrm{mg} / \mathrm{mq} \text { every } 4 \text { weeks, JM8 AUC5 + paclitaxel } 175 \mathrm{mg} / \mathrm{mq}+\text { topotecam } 1 \mathrm{mg} / \mathrm{mq} \text { per } 3 \text { days every } 3 \text { weeks). }\end{array}$ \\
\hline $\begin{array}{l}\text { Guardiola et al., } 2010 \\
\text { [29] }\end{array}$ & Chemotherapy with platinum-containing regimens. \\
\hline $\begin{array}{l}\text { Saadeh et al., } 2013 \\
\text { [30] }\end{array}$ & Adjuvant and neoadjuvant chemotherapy (details were unavailable). \\
\hline Pant et al., 2014 [31] & Frontline adjuvant chemotherapy (details were unavailable). \\
\hline $\begin{array}{l}\text { Chavan et al., } 2017 \\
\text { [15] }\end{array}$ & Adjuvant and neoadjuvant chemotherapy (details were unavailable). \\
\hline Greco et al., 2017 [32] & Neoadjuvant chemotherapy (details were unavailable). \\
\hline Kuk et al., 2017 [33] & $\begin{array}{l}\text { The control group ( } 26 \text { patients) was treated with three to six cycles of standard first-line chemotherapy consisting of carbo- } \\
\text { platin (AUC } 6 \text { i.v.) and paclitaxel }\left(175 \mathrm{mg} / \mathrm{m}^{2} \text { i.v.) (CP). The study group ( } 31 \text { patients) was treated with CP chemotherapy with }\right. \\
\text { the addition of bevacizumab ( } 7.5 \mathrm{mg} / \mathrm{kg} \text { bw i.v.). }\end{array}$ \\
\hline Zhang et al., 2018 [16] & Neoadjuvant chemotherapy with carboplatin paclitaxel was administered for 2 or 3 courses before cytoreductive surgery. \\
\hline $\begin{array}{l}\text { Salinaro et al., } 2020 \\
\text { [17] }\end{array}$ & Neoadjuvant chemotherapy (details were unavailable). \\
\hline
\end{tabular}

prevalence of included studies with sample size $>500$ was lower than that in sample size $\leq 500$. We also performed sensitivity analysis to explore the robustness of the overall pooled estimate. The pooled effects of sensitivity analysis remained slight fluctuation, which suggested that the current pooled estimate was robust and credible. To clarify the prevalence of VTE in different clinical settings, we performed subgroup analysis based on publication time, region, disease stages, operation type, VTE diagnostic criterion, study design, and NOS score. We found that the prevalences were basically consistent with the overall pooled effect in subgroups based on region, disease stages, operation type, study design, and NOS score. The prevalence of VTE in the sub-populations with publication time $\leq 2009$ was relatively lower than that in publication time $>2010$. Understandably, the proportion of $\mathrm{OC}$ increased significantly in recent years $[34,35]$. Machida et al. found that clear cell carcinoma has increased significantly between 2002 and 2010 which accounted for nearly $30 \%$ of epithelial OC in Japan [34]. Althubiti and coworkers showed that the incidence of $\mathrm{OC}$

Table 3 NOS scores of studies included in the meta-analysis

\begin{tabular}{|c|c|c|c|c|}
\hline Author, year & Selection & Comparability & Outcome/exposure & Total score \\
\hline Fotopoulou et al., 2008 [27] & $* * * *$ & ** & ** & 8 \\
\hline Fotopoulou et al., 2009 [14] & $* * * *$ & $* *$ & $* *$ & 8 \\
\hline Mereu et al., 2009 [28] & $* * *$ & * & $* *$ & 6 \\
\hline Guardiola et al., 2010 [29] & $* * *$ & * & * & 5 \\
\hline Saadeh et al., 2013 [30] & $* * * *$ & $* *$ & $* *$ & 8 \\
\hline Pant et al., 2014 [31] & $* * *$ & $* *$ & $* *$ & 7 \\
\hline Chavan et al., 2017 [15] & $* * * *$ & $* *$ & $* *$ & 8 \\
\hline Greco et al., 2017 [32] & $* * * *$ & $* *$ & $* *$ & 8 \\
\hline Kuk et al., 2017 [33] & $* * * *$ & $* *$ & * & 7 \\
\hline Zhang et al., 2018 [16] & $* * * *$ & $* *$ & $* *$ & 8 \\
\hline Salinaro et al., 2020 [17] & $* * * *$ & $* *$ & * & 7 \\
\hline
\end{tabular}




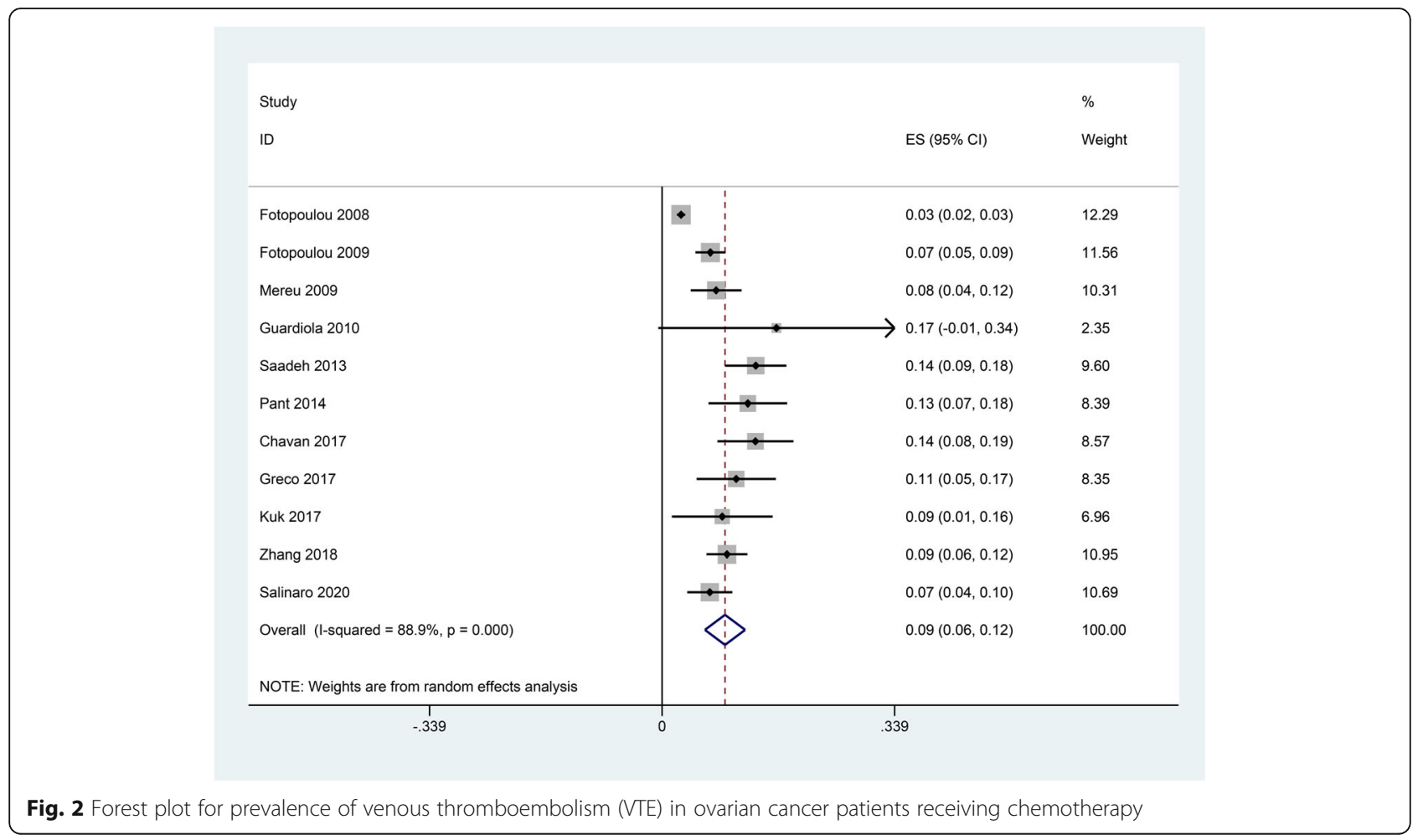

increased around 4-fold in Saudi Arabia between 1990 and 2016 [35]. Interestingly, increasing evidence investigated that advanced age was a significant risk factor for VTE [36, 37]. Therefore, a possible interpretation is that the prevalence difference of VTE between publication time $\leq 2009$ and $>2010$ may be attributed to an aging population in recent years.

We also explored the potential risk factors associated with VTE in OC patients receiving chemotherapy. Some significant risk factors were identified to be significant predictors for chemotherapy-associated VTE including advanced age, ascites, D-dimer $>0.5 \mathrm{mg} / \mathrm{mL}$, and tumor diameter $>10 \mathrm{~cm}$. Actually, mountains of studies found that advanced age was a significant predictor for VTE in patients. Stämpfli and colleagues found that endothelial dysfunction was a critical inducer to VTE and aging was associated with endothelial dysfunction [38]. Further study showed that senescence-induced oxidative stress may be an important contributor to link aging with endothelial dysfunction [39]. Ascites was also identified to be an important risk factor for VTE in OC patients receiving chemotherapy. Consistent with our systematic review, several studies showed that ascites was associated with VTE in patients with cancer, especially gynecological cancer [40-42]. Peripheral blood of patients with cancer is usually in hypercoagulable state, which may be worsened owing to ascites, a frequent event in patients with cancer, especially advanced cancer. Moreover, ascites was associated with reduced relative blood volume. All of these can explain the mechanism linking ascites to chemotherapy-associated VTE in OC. D-dimer level was regarded as a typical signature for VTE, and a meta-analysis also showed that the plasma D-dimer level correlated with disease progression and the VTE risk in patients with ovarian cancer [43]. In the current meta-analysis, only one included study found that D-dimer $>0.5 \mathrm{mg} / \mathrm{mL}$ was a significant risk factor for VTE in OC patients receiving chemotherapy. Interestingly, two included studies reported the role of chemotherapy-associated VTE on prognosis of OC patients with conflicting results [14, 27]. Regardless of the inconsistence, high level of plasma D-dimer level in OC patients undergoing chemotherapy should be vigilant and relevant preventive measures against VTE should be considered. BMI and obesity are reportedly associated with VTE in the general population [44-46], but the current available evidence in our systematic review did not determine whether BMI or obesity was a significant risk factor for chemotherapy-related VTE in OC. Fotopoulou et al. revealed that BMI $<30 \mathrm{~kg} / \mathrm{m}^{2}$ was associated with approximately 3.2-fold increase of VTE in OC patients undergoing platinum/paclitaxel-containing first-line chemotherapy [27]. However, another study found that $\mathrm{BMI}<30 \mathrm{~kg} / \mathrm{m}^{2}$ was not a significant risk factor for chemotherapy-related VTE in OC [14]. Considering that hyperlipidemia was associated with VTE 


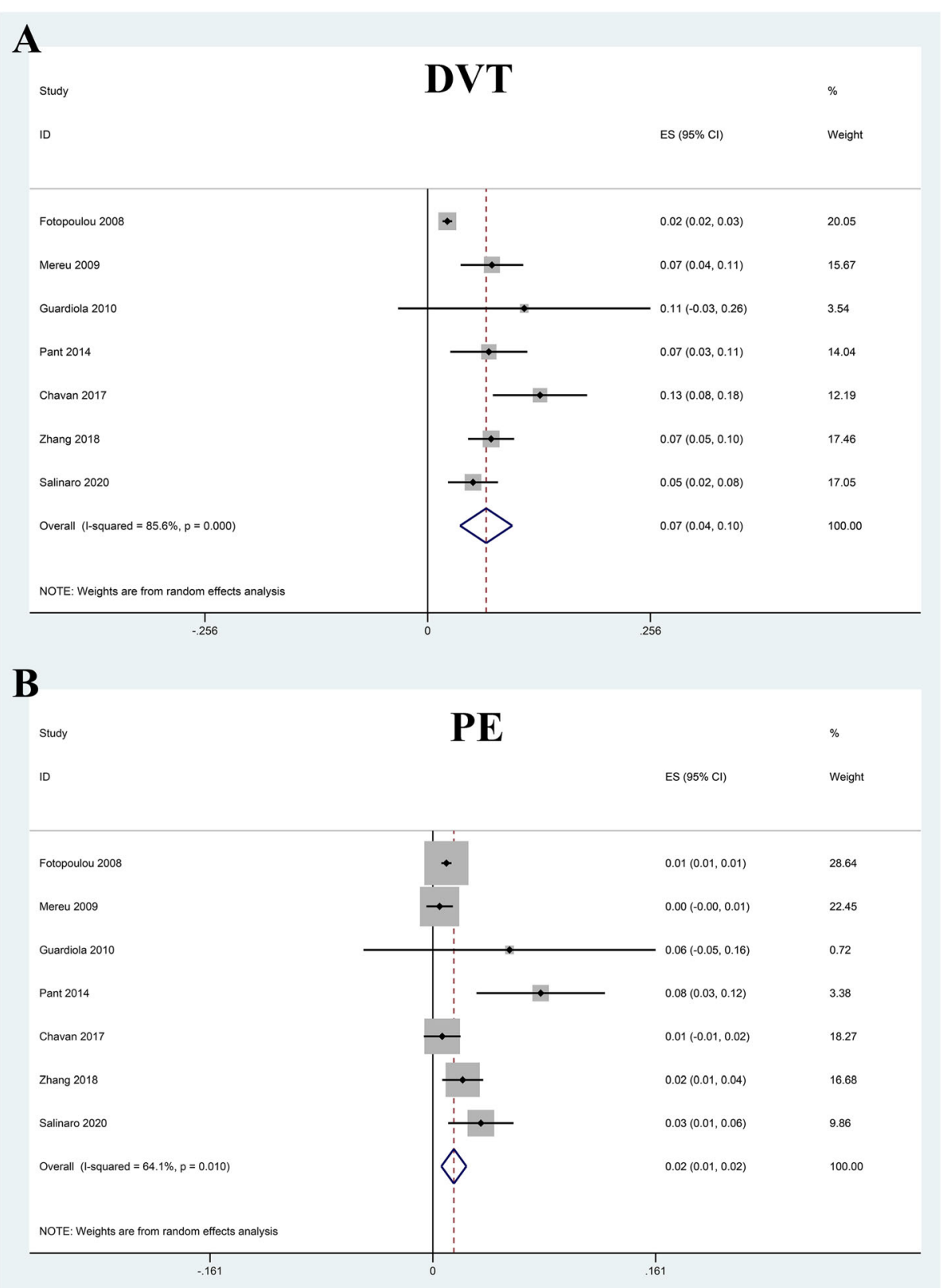

Fig. 3 Forest plot for prevalence of deep venous thrombosis (DVT) and pulmonary embolism (PE) in ovarian cancer patients receiving chemotherapy

[47], the potential role of BMI or obesity in VTE development should be further studied. Therefore, whether BMI or obesity was a significant predictor for chemotherapy-related VTE in OC requires further investigation.

Several limitations also existed in our study. Firstly, the current study only included studies in Asia, Europe, and the USA, although we did not impose any restrictions in regions when we performed literature search.
Therefore, regardless of the fact that the prevalence of chemotherapy-related VTE in OC was basically consistent in these regions, the results may not be generalizable to other non-involved areas, such as Africa and Australia. Secondly, there existed substantial statistical heterogeneity across included studies in the metaanalysis. Meta-regression analysis identified that sample size was a potential source of statistical heterogeneity. Irrespective of statistical heterogeneity, the results of 
Table 4 Subgroup analysis for the prevalence of venous thromboembolism in ovarian cancer patients receiving chemotherapy

\begin{tabular}{|c|c|c|c|}
\hline Subgroups & No. of studies & Pooled rate with $95 \% \mathrm{Cl}$ & $I^{2}(\%)$ \\
\hline The overall pooled result & 11 & $0.09(0.06,0.12)$ & 88.9 \\
\hline \multicolumn{4}{|l|}{ Publication time } \\
\hline$\leq 2009$ & 3 & $0.06(0.02,0.09)$ & 89.9 \\
\hline$>2010$ & 8 & $0.10(0.08,0.12)$ & 22.8 \\
\hline \multicolumn{4}{|l|}{ Region } \\
\hline Asia & 2 & $0.11(0.07-0.15)$ & 40 \\
\hline Europe & 6 & $0.08(0.04-0.12)$ & 88.9 \\
\hline The USA & 3 & $0.09(0.06-0.13)$ & 38.9 \\
\hline \multicolumn{4}{|l|}{ Disease status } \\
\hline Ovarian cancer & 5 & $0.10(0.07-0.12)$ & 52.7 \\
\hline Advanced ovarian cancer & 4 & $0.08(0.02-0.14)$ & 85.4 \\
\hline Recurrent ovarian cancer & 2 & $0.08(0.03-0.13)$ & 15.3 \\
\hline \multicolumn{4}{|l|}{ Operation type } \\
\hline Debulking surgery & 6 & $0.08(0.04-0.12)$ & 85.7 \\
\hline Radical surgery & 5 & $0.10(0.07-0.13)$ & 65.7 \\
\hline \multicolumn{4}{|l|}{ Sample size } \\
\hline$\leq 500$ & 9 & $0.10(0.08-0.12)$ & 22.2 \\
\hline$>500$ & 2 & $0.05(0.01-0.09)$ & 92.6 \\
\hline \multicolumn{4}{|l|}{ VTE diagnostic criterion } \\
\hline Self-definition & 8 & $0.10(0.08-0.12)$ & 27.6 \\
\hline CTC & 3 & $0.05(0.01-0.10)$ & 87.5 \\
\hline \multicolumn{4}{|l|}{ Study design } \\
\hline Case-control & 6 & $0.09(0.05-0.13)$ & 91.9 \\
\hline Cross-sectional study & 2 & $0.08(0.05-0.12)$ & 0 \\
\hline Retrospective cohort & 3 & $0.10(0.06-0.14)$ & 55.6 \\
\hline \multicolumn{4}{|l|}{ NOS score } \\
\hline$\leq 6$ & 2 & $0.08(0.05-0.12)$ & 0 \\
\hline$>6$ & 9 & $0.09(0.06-0.12)$ & 90.4 \\
\hline
\end{tabular}

subsequent subgroup analysis and sensitivity analysis were basically consistent with the overall pooled estimate, which indicated that the pooled prevalence was reliable and credible. Thirdly, the potential publication bias cannot be excluded in the meta-analysis, although we performed a comprehensive literature search. Regardless of the significant publication bias, the sensitivity analysis based on the trim-and-fill method indicated that the pooled estimate was basically consistent with the previous one after adding two "missing studies." Finally, owing to inconsistent methodology description on risk factors in included studies, we only performed systematic reviews, but not meta-analysis for them, so correlative dimension of these risk factors with chemotherapyrelated VTE was largely unclear. Moreover, there are other factors like anesthesia condition, clinic care, and other related health conditions which were not identified in the current meta-analysis, but may also be potential risk factors for chemotherapy-related VTE. Accordingly, these results may put cautious interpretation and further studies focused on these important risk factors should be warranted, which contributes to improving or controlling critical risk factors for chemotherapy-related VTE in OC.

\section{Conclusion}

This current study revealed that the pooled prevalence of chemotherapy-related VTE in OC was approximately $9 \%$ in OC patients. Many risk factors were significant predictors for chemotherapy-related VTE including advanced age, D-dimer $>0.5 \mathrm{mg} / \mathrm{mL}$, and tumor diameter $>10 \mathrm{~cm}$. Future high-quality studies should be warranted to investigating the benefits of prevention strategies for chemotherapy-related VTE in OC patients. 


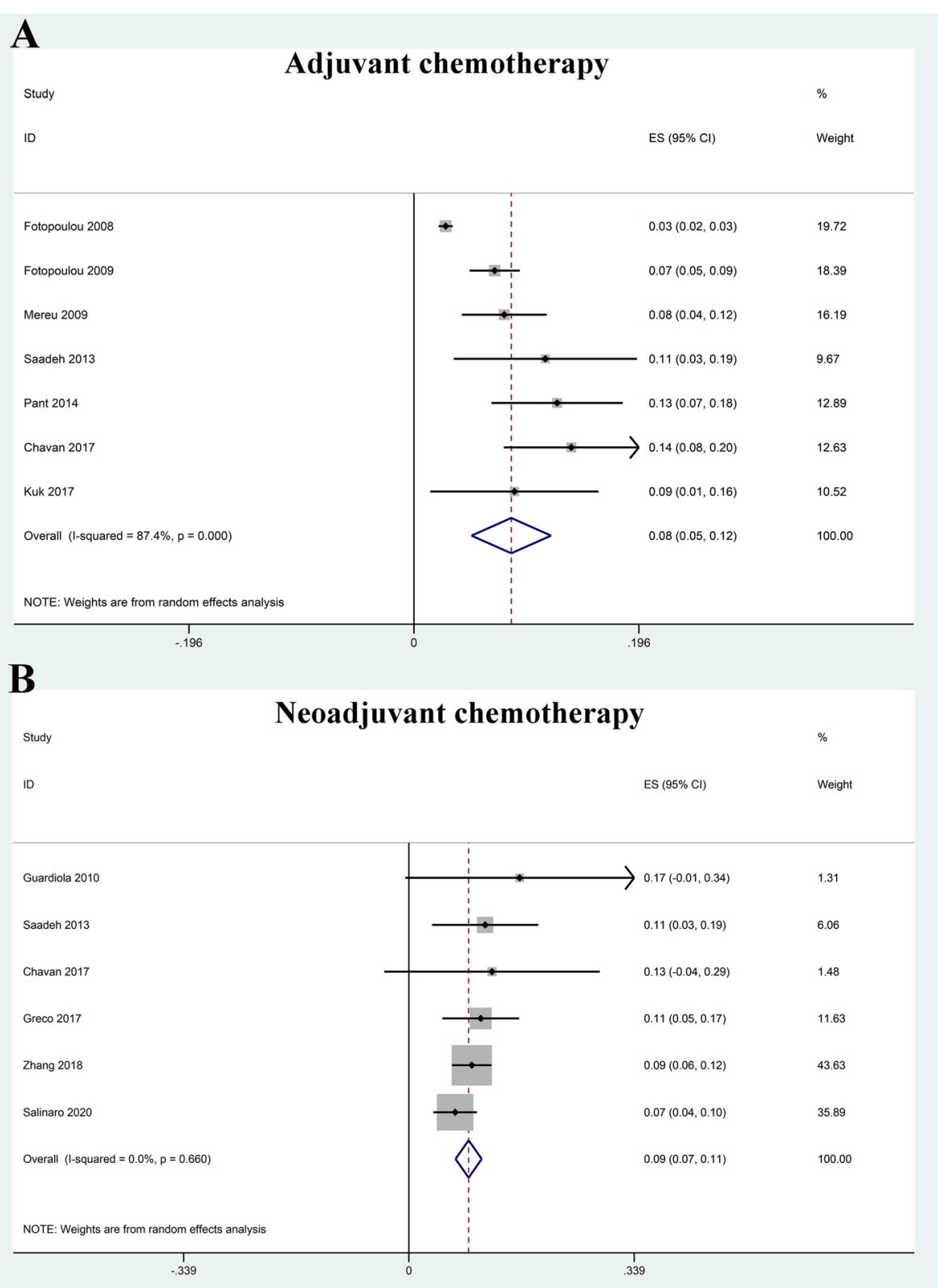

Fig. 4 Forest plot for prevalence of venous thromboembolism (VTE) in ovarian cancer patients receiving adjuvant chemotherapy (a) and neoadjuvant chemotherapy (b) 


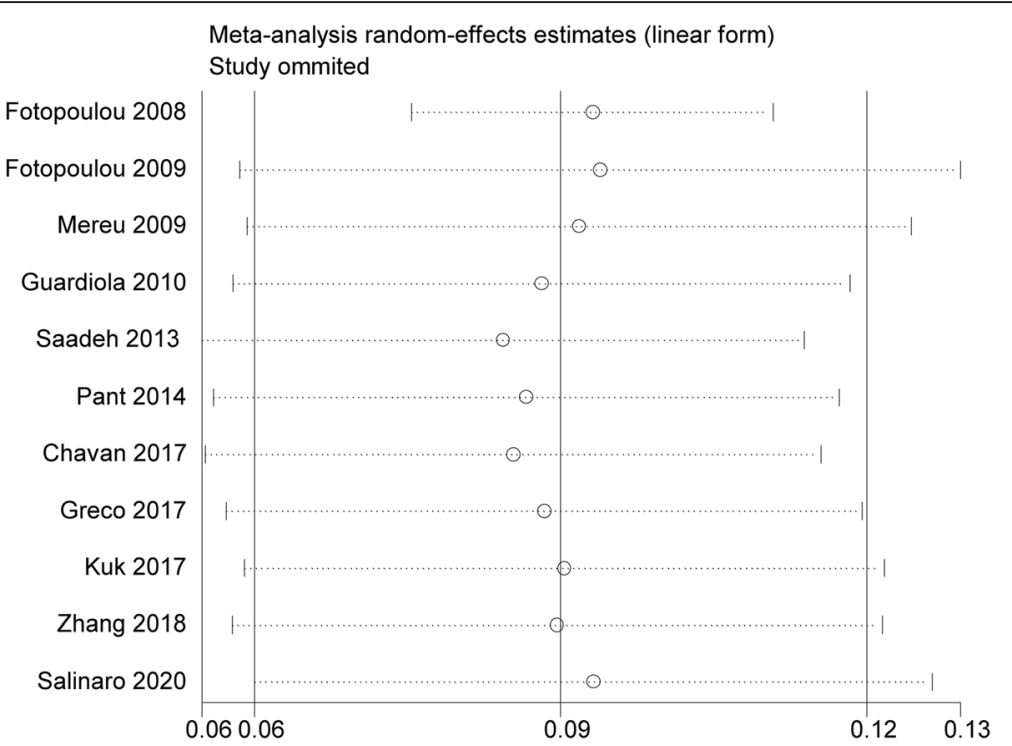

Fig. 5 Sensitivity analyses for prevalence of venous thromboembolism (VTE) in ovarian cancer patients receiving chemotherapy

Filled funnel plot with pseudo $95 \%$ confidence limits

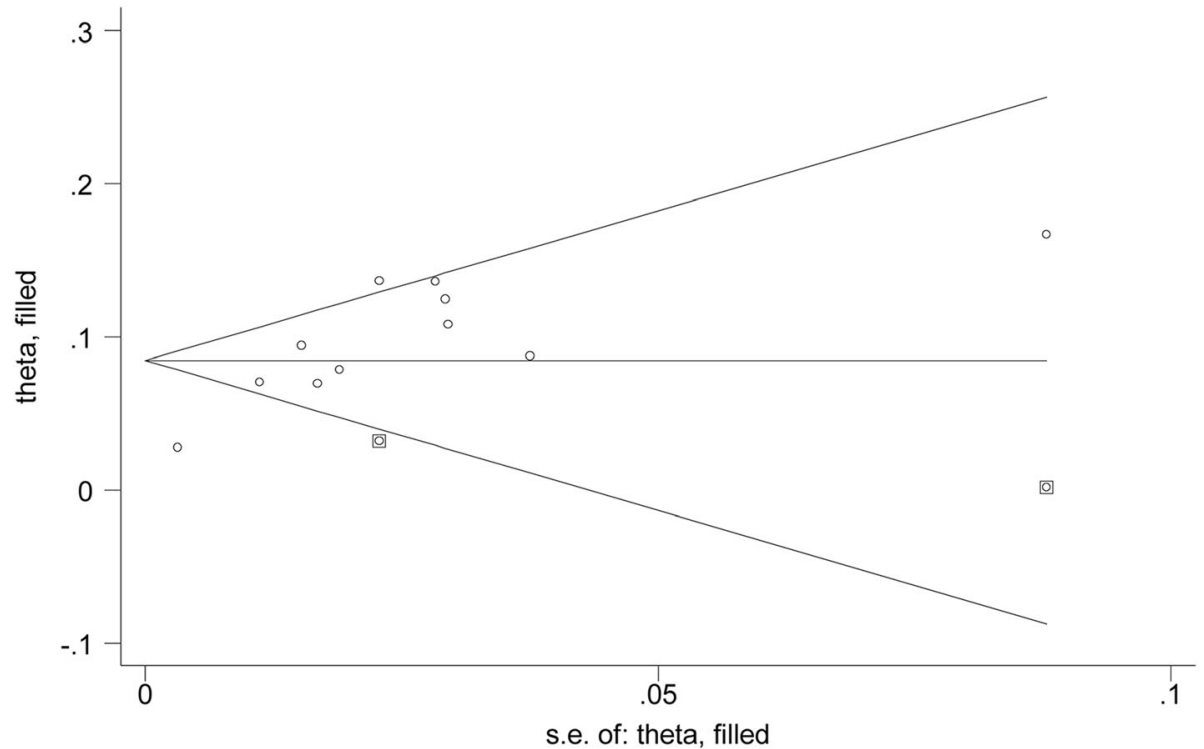

Fig. 6 Adjusted funnel plot of chemotherapy-associated venous thromboembolism in ovarian cancer after adding two "missing" studies from the "trim-and-fill" analysis

Table 5 Risk factors associated with VTE on multivariate model in ovarian cancer patients receiving chemotherapy

\begin{tabular}{|c|c|}
\hline Study & Risk factors on multivariate model \\
\hline $\begin{array}{l}\text { Fotopoulou et al. } \\
\text { [27] }\end{array}$ & $\begin{array}{l}\text { Age (35-81 years): HR 1.4, 95\% Cl 1.1-1.8; BMI < } 30 \text { kg/m²: HR 3.2, 95\% Cl 2.0-5.2; FIGO IIIC or IV: HR 1.0, 95\% Cl 0.6-1.7; chemotherapy: HR 0.2, 95\% } \\
\text { Cl 0.1-0.7; ascites: HR 1.5, 95\% Cl 0.9-2.3; para-aortic lymphadenectomy: HR 0.5, 95\% Cl 0.3-1.0; pelvic lymphadenectomy: HR 1.1, 95\% Cl 0.6-2.0 }\end{array}$ \\
\hline $\begin{array}{l}\text { Fotopoulou et al. } \\
{[14]}\end{array}$ & $\begin{array}{l}\text { Age < } 60 \text { years: HR 1.26, 95\% Cl 0.58-2.71; BMI < } 30 \mathrm{~kg} / \mathrm{m}^{2} \text { : HR 1.07, 95\% Cl 0.49-2.36; ECOG: HR 0.89, 95\% Cl 0.42-1.87; platinum-sensitive: HR 1.16, } \\
95 \% \text { Cl 0.56-2.4; serous-papillary: HR 0.64, 95\% Cl 0.29-1.38; ascites: HR 2.2, 95\% Cl 1.02-4.72; surgery: HR 0.58, 95\% Cl 0.24-1.36; new relapse: HR } \\
0.64,95 \% \text { Cl 0.26-1.53 }\end{array}$ \\
\hline Mereu et al. [28] & $\begin{array}{l}\text { Age: HR 1.27, 95\% Cl 0.94-1.70; BMI: HR 1.62,95\% Cl 1.08-2.42; FIGO stage: HR 7.14, 95\% Cl 0.81-62.89; histologic diagnosis: HR 0.20, 95\% Cl 0.05- } \\
\text { 0.78; mono-chemotherapy: HR 4.97, 95\% Cl 1.50-16.49; risk category: HR 2.81, 95\% Cl 0.88-8.96 }\end{array}$ \\
\hline Chavan et al. [15] & Neoadjuvant chemotherapy: RR 0.90, 95\% Cl 0.23-3.56; menopausal: RR 3.2, 95\% Cl 0.95-10.09 \\
\hline Zhang et al. [16] & $\begin{array}{l}\text { Age > } 55 \text { years: OR 13.110, 95\% Cl 2.451-70.133; PLT > } 300 \text { 109/L: OR 3.987, 95\% Cl 1.085-14.657; D-dimer > 0.5 mg/mL: OR 17.317, 95\% Cl 3.485- } \\
\text { 86.057; tumor diameter > } 10 \text { cm: OR 4.93, 95\% Cl 1.364-17.819 }\end{array}$ \\
\hline
\end{tabular}




\section{Supplementary Information}

The online version contains supplementary material available at https://doi. org/10.1186/s12957-020-02101-5.

Additional file 1. The detailed search strategy.

\section{Abbreviations}

OC: Ovarian cancer; VTE: Venous thromboembolism; PE: Pulmonary embolus; RR: Relative risk; OR: Odds ratio; Cl: Confidence interval; NOS: NewcastleOttawa Scale

\section{Acknowledgements}

The authors would like to thank the editors and reviewers for their suggestions.

\section{Authors' contributions}

Lu Ye, Li Cai, Yonghui Fu, and Youkun Jie: literature searching, data collection, and manuscript writing. Debao Zhuang, Xiaoqing $\mathrm{Hu}$, and Youkun Jie: manuscript writing, data management, and data analysis. Lu Ye, Li Cai, Yonghui Fu, Xiaoqing Hu, and Youkun Jie: data collection and data interpretation. Debao Zhuang and Xiaoqing Hu: literature searching. Lu Ye, Li Cai, Yonghui Fu, Xiaoging Hu, and Youkun Jie: conception, design, and revision of the manuscript. The authors read and approved the final manuscript.

\section{Funding}

None.

\section{Availability of data and materials}

All the data and material are available.

\section{Ethics approval and consent to participate}

This article does not contain any studies with human or animal subjects performed by any of the authors.

\section{Consent for publication \\ Approved.}

\section{Competing interests}

The authors declare that they have no conflict of interest.

\section{Author details}

'Department of Pathology, Jiangxi Maternal and Child Health Hospital, Nanchang 330006, Jiangxi, China. ²Department of Oncology, Jiangxi Maternal and Child Health Hospital, Nanchang 330006, Jiangxi, China. ${ }^{3}$ Department of Psychiatry, Jiangxi Mental Hospital/Affiliated Mental Hospital of Nanchang University, Nanchang 330029, Jiangxi, China.

Received: 4 September 2020 Accepted: 27 November 2020 Published online: 13 January 2021

\section{References}

1. Merkow RP, Bilimoria KY, McCarter MD, Cohen ME, Barnett CC, Raval MV, Caprini JA, Gordon HS, Ko CY, Bentrem DJ. Post-discharge venous thromboembolism after cancer surgery: extending the case for extended prophylaxis. Ann Surg. 2011;254(1):131-7. https://doi.org/10.1097/SLA. Ob013e31821b98da.

2. Ratib S, Walker AJ, Card TR, Grainge MJ. Risk of venous thromboembolism in hospitalised cancer patients in England-a cohort study. J Hematol Oncol. 2016;9(1):60. https://doi.org/10.1186/s13045-016-0291-0.

3. Satoh T, Oki A, Uno K, Sakurai M, Ochi H, Okada S, Minami R, Matsumoto K, Tanaka YO, Tsunoda H, Homma S, Yoshikawa H. High incidence of silent venous thromboembolism before treatment in ovarian cancer. $\mathrm{Br} J$ Cancer. 2007;97(8):1053-7. https://doi.org/10.1038/sj.bjc.6603989.

4. Takasaki K, Miyamoto M, Takano M, Soyama H, Aoyama T, Matsuura H, Iwahashi H, Ishibashi H, Sakamoto T, Furuya K. Thrombotic events induce the worse prognosis in ovarian carcinomas and frequently develop in ovarian clear cell carcinoma. Int J Clin Oncol. 2019:24(10):1273-83. https:// doi.org/10.1007/s10147-019-01464-4.
5. Mittal V, Ahuja S, Vejella SS, Stempel JM, Palabindala V, Dourado CM, Leighton JC. Trends and outcomes of venous thromboembolism in hospitalized patients with ovarian cancer: results from nationwide inpatient sample database 2003 to 2011. Int J Gynecol Cancer. 2018;28(8):1478-84. https://doi.org/10.1097/igc.0000000000001335.

6. Lyman GH, Culakova E, Poniewierski MS, Kuderer NM. Morbidity, mortality and costs associated with venous thromboembolism in hospitalized patients with cancer. Thromb Res. 2018;164(Suppl 1):S112-s118. https://doi. org/10.1016/j.thromres.2018.01.028.

7. Zhou Q, Zhu C, Shen Z, Zhang T, Li M, Zhu J, Qin J, Xie Y, Zhang W, Chen R, Wang G, Qian L, Wu D, Nashan B, Zhou Y. Incidence and potential predictors of thromboembolic events in epithelial ovarian carcinoma patients during perioperative period. Eur J Surg Oncol. 2020. https://doi.org/ 10.1016/j.ejso.2020.01.026.

8. Wu X, Xue X, Tang J, Cheng X, Tian W, Jiang R, Zang R. Evaluation of risk factors for venous thromboembolism in Chinese women with epithelial ovarian cancer. Int J Gynecol Cancer. 2013;23(1):65-72. https://doi.org/10. 1097/IGC.0b013e318276dd87.

9. Wright AA, Bohlke K, Armstrong DK, Bookman MA, Cliby WA, Coleman RL, Dizon DS, Kash JJ, Meyer LA, Moore KN, Olawaiye AB, Oldham J, Salani R, Sparacio D, Tew WP, Vergote I, Edelson MI. Neoadjuvant chemotherapy for newly diagnosed, advanced ovarian cancer: Society of Gynecologic Oncology and American Society of Clinical Oncology clinical practice guideline. J Clin Oncol. 2016;34(28):3460-73. https://doi.org/10.1200/jco. 2016.68.6907.

10. Ray-Coquard I, Morice P, Lorusso D, Prat J, Oaknin A, Pautier P, Colombo N. Non-epithelial ovarian cancer: ESMO Clinical Practice Guidelines for diagnosis, treatment and follow-up. Ann Oncol. 2018;29(Suppl 4):iv1-iv18. https://doi.org/10.1093/annonc/mdy001.

11. Lawrie TA, Winter-Roach BA, Heus P, Kitchener HC. Adjuvant (post-surgery) chemotherapy for early stage epithelial ovarian cancer. Cochrane Database Syst Rev. 2015;12:Cd004706. https://doi.org/10.1002/14651858.CD004706. pub5.

12. Khorana AA, Dalal M, Lin J, Connolly GC. Incidence and predictors of venous thromboembolism (VTE) among ambulatory high-risk cancer patients undergoing chemotherapy in the United States. Cancer. 2013;119(3):648-55. https://doi.org/10.1002/cncr.27772.

13. Di Nisio M, Candeloro M, Rutjes AWS, Porreca E. Venous thromboembolism in cancer patients receiving neoadjuvant chemotherapy: a systematic review and meta-analysis. J Thromb Haemost. 2018;16(7):1336-46. https:// doi.org/10.1111/jth.14149.

14. Fotopoulou C, Karavas A, Trappe R, Chekerov R, Lichtenegger W, Sehouli J. Venous thromboembolism in recurrent ovarian cancer-patients: a systematic evaluation of the North-Eastern German Society of Gynaecologic Oncology Ovarian Cancer Study Group (NOGGO). Thromb Res. 2009;124(5):531-5. https://doi.org/10.1016/j.thromres.2009.03.013.

15. Chavan DM, Huang $Z$, Song $K$, Parimi LRH, Yang XS, Zhang $X$, Liu $P$, Jiang J, Zhang Y, Kong B, Li L. Incidence of venous thromboembolism following the neoadjuvant chemotherapy regimen for epithelial type of ovarian cancer. Medicine. 2017;96(42):e7935. https://doi.org/10.1097/md. 0000000000007935

16. Zhang W, Liu X, Cheng H, Yang Z, Zhang G. Risk factors and treatment of venous thromboembolism in perioperative patients with ovarian cancer in China. Medicine. 2018;97(31):e11754. https://doi.org/10.1097/md. 0000000000011754.

17. Salinaro JR, McQuillen $K$, Stemple M, Boccaccio R, Ehrisman J, Lorenzo AM, Havrilesky L, Secord AA, Galvan Turner V, Moore KN, Davidson B. Incidence of venous thromboembolism among patients receiving neoadjuvant chemotherapy for advanced epithelial ovarian cancer. Int J Gynecol Cancer. 2020;30(4):491-7. https://doi.org/10.1136/ijgc-2019-000980.

18. Stroup DF, Berlin JA, Morton SC, Olkin I, Williamson GD, Rennie D, Moher D, Becker BJ, Sipe TA, Thacker SB. Meta-analysis of observational studies in epidemiology: a proposal for reporting. Meta-analysis Of Observational Studies in Epidemiology (MOOSE) group. Jama. 2000;283(15):2008-12. https://doi.org/10.1001/jama.283.15.2008.

19. Stang A. Critical evaluation of the Newcastle-Ottawa scale for the assessment of the quality of nonrandomized studies in meta-analyses. Eur J Epidemiol. 2010;25(9):603-5. https://doi.org/10.1007/s10654-0109491-z.

20. DerSimonian R, Laird N. Meta-analysis in clinical trials. Control Clin Trials. 1986;7(3):177-88. https://doi.org/10.1016/0197-2456(86)90046-2. 
21. Higgins JP, Thompson SG, Deeks JJ, Altman DG. Measuring inconsistency in meta-analyses. BMJ (Clinical research ed). 2003;327(7414):557-60. https://doi. org/10.1136/bmj.327.7414.557.

22. Huedo-Medina TB, Sanchez-Meca J, Marin-Martinez F, Botella J. Assessing heterogeneity in meta-analysis: Q statistic or 12 index? Psychol Methods. 2006;11(2):193-206. https://doi.org/10.1037/1082-989x.11.2.193.

23. Begg CB, Mazumdar M. Operating characteristics of a rank correlation test for publication bias. Biometrics. 1994;50(4):1088-101.

24. Egger M, Davey Smith G, Schneider M, Minder C. Bias in meta-analysis detected by a simple, graphical test. BMJ (Clinical research ed). 1997; 315(7109):629-34. https://doi.org/10.1136/bmj.315.7109.629.

25. Duval S, Tweedie R. Trim and fill: a simple funnel-plot-based method of testing and adjusting for publication bias in meta-analysis. Biometrics. 2000; 56(2):455-63. https://doi.org/10.1111/j.0006-341x.2000.00455.x.

26. Shi $L$, Lin $L$. The trim-and-fill method for publication bias: practical guidelines and recommendations based on a large database of metaanalyses. Medicine. 2019;98(23):e15987. https://doi.org/10.1097/md. 0000000000015987.

27. Fotopoulou C, duBois A, Karavas AN, Trappe R, Aminossadati B, Schmalfeldt B, Pfisterer J, Sehouli J. Incidence of venous thromboembolism in patients with ovarian cancer undergoing platinum/paclitaxel-containing first-line chemotherapy: an exploratory analysis by the Arbeitsgemeinschaft Gynaekologische Onkologie Ovarian Cancer Study Group. J Clin Oncol. 2008;26(16):2683-9. https://doi.org/10. 1200/jco.2008.16.1109.

28. Mereu L, Tateo S, Klersy C, Martinotti Gabellotti E, Polatti F. Stratification of venous thromboembolism risk in ovarian cancer patients during chemotherapy. Int J Gynecol Cancer. 2009;19(1):79-83. https://doi.org/10. 1111/IGJ.0b013e318199035e.

29. Guardiola E, Chauffert B, Delroeux D, Royer B, Heyd B, Combe M, Benoit L, Causeret S, Demarchi M, Magnin G, Mayer F, Tixier H, Pivot X. Intraoperative chemotherapy with cisplatin and epinephrine after cytoreductive surgery in patients with recurrent ovarian cancer: a phase I study. Anti Cancer Drugs. 2010;21(3):320-5. https://doi.org/10.1097/CAD.0b013e328334d953.

30. Abu Saadeh F, Norris L, O'Toole S, Gleeson N. Venous thromboembolism in ovarian cancer: incidence, risk factors and impact on survival. Eur J Obstet Gynecol Reprod Biol. 2013;170(1):214-8. https://doi.org/10.1016/j.ejogrb. 2013.06.004.

31. Pant A, Liu D, Schink J, Lurain J. Venous thromboembolism in advanced ovarian cancer patients undergoing frontline adjuvant chemotherapy. Int J Gynecol Cancer. 2014;24(6):997-1002. https://doi.org/10.1097/igc. 0000000000000164.

32. Greco PS, Bazzi AA, McLean K, Reynolds RK, Spencer RJ, Johnston CM, Liu JR, Uppal S. Incidence and timing of thromboembolic events in patients with ovarian cancer undergoing neoadjuvant chemotherapy. Obstet Gynecol. 2017;129(6):979-85. https://doi.org/10.1097/aog. 0000000000001980

33. Kuk A, Magnowska M, Suchy W, Swierczynska J, Zaborowski MP, Gaca M, Nowak-Markwitz E. Retrospective evaluation of thromboembolism risk in ovarian cancer patients treated with bevacizumab. Target Oncol. 2017;12(4): 495-503. https://doi.org/10.1007/s11523-017-0496-3.

34. Machida H, Matsuo K, Yamagami W, Ebina Y, Kobayashi Y, Tabata T, Kanauchi M, Nagase S, Enomoto T, Mikami M. Trends and characteristics of epithelial ovarian cancer in Japan between 2002 and 2015: a JSGO-JSOG joint study. Gynecol Oncol. 2019;153(3):589-96. https://doi.org/10.1016/j. ygyno.2019.03.243

35. Althubiti MA, Nour Eldein MM. Trends in the incidence and mortality of cancer in Saudi Arabia. Saudi Med J. 2018;39(12):1259-62. https://doi.org/10. 15537/smj.2018.12.23348.

36. Pellino G, Sciaudone G, Candilio G, De Fatico GS, Canonico S, Selvaggi F. Predictors of venous thromboembolism after colorectal surgery in a single unit. Acta Chir Belg. 2015;115(4):288-92. https://doi.org/10.1080/00015458. 2015.11681114.

37. Kraaijpoel N, Carrier M. How I treat cancer-associated venous thromboembolism. Blood. 2019;133(4):291-8. https://doi.org/10.1182/blood2018-08-835595

38. Stampfli SF, Akhmedov A, Gebhard C, Lohmann C, Holy EW, Rozenberg I, Spescha R, Shi Y, Luscher TF, Tanner FC, Camici GG. Aging induces endothelial dysfunction while sparing arterial thrombosis. Arterioscler Thromb Vasc Biol. 2010;30(10):1960-7. https://doi.org/10.1161/atvbaha.110. 206920
39. Bhayadia R, Schmidt BM, Melk A, Homme M. Senescence-induced oxidative stress causes endothelial dysfunction. J Gerontol Ser A Biol Sci Med Sci. 2016;71(2):161-9. https://doi.org/10.1093/gerona/glv008.

40. Hosokawa Y, Takao W, Itagaki H, Nishida K, Akiyama A, Shikama A, Ochi H, Satoh T, Takayoshi K, Kusaba H, Aikawa T, Koreishi S, Sagara K, Nakano M, Komoda M, Kono M, Fukata M, Arita T, Esaki T, Akashi K, Baba E. Hypoalbuminemia for the prediction of venous thromboembolism and treatment of direct oral anticoagulants in metastatic gastric cancer patients. J Obstet Gynaecol Res. 2019;22(5):988-98 https://doi.org/10.1111/jog.14233. https://doi.org/10.1007/s10120-019-00930-2.

41. Kodama J, Seki N, Fukushima C, Kusumoto T, Nakamura K, Hongo A, Hiramatsu Y. Elevated preoperative plasma D-dimer levels and the incidence of venous thromboembolism in Japanese females with gynecological cancer. Gastric Cancer. 2013;5(1):299-304 https://doi.org/10. 1007/s10120-019-00930-2. https://doi.org/10.3892/ol.2012.970.

42. Tasaka N, Minaguchi T. Prevalence of venous thromboembolism at pretreatment screening and associated risk factors in 2086 patients with gynecological cancer; 2020. https://doi.org/10.1111/jog.14233.

43. Wu J, Fu Z, Liu G, Xu P, Xu J, Jia X. Clinical significance of plasma D-dimer in ovarian cancer: a meta-analysis. Medicine (Baltimore). 2017;96(25):e7062. https://doi.org/10.1097/MD.0000000000007062.

44. Tan L, Qi B, Yu T, Wang C. Incidence and risk factors for venous thromboembolism following surgical treatment of fractures below the hip: a meta-analysis. Int Wound J. 2016;13(6):1359-71. https://doi.org/10.1111/ iwj.12533.

45. Blondon M, Casini A, Hoppe KK, Boehlen F, Righini M, Smith NL. Risks of venous thromboembolism after cesarean sections: a meta-analysis. Chest. 2016;150(3):572-96. https://doi.org/10.1016/j.chest.2016.05.021.

46. Wattanakit K, Lutsey PL, Bell EJ, Gornik H, Cushman M, Heckbert SR, Rosamond WD, Folsom AR. Association between cardiovascular disease risk factors and occurrence of venous thromboembolism. A time-dependent analysis. Thromb Haemost. 2012;108(3):508-15. https://doi.org/10.1160/th1110-0726.

47. Zamani A, Omrani GR, Lankarani KB. Hyperhomocysteinaemia, hyperlipidaemia and risk of venous thromboembolism in Shiraz. East Mediterr Health J. 2003;9(5-6):935-43.

\section{Publisher's Note}

Springer Nature remains neutral with regard to jurisdictional claims in published maps and institutional affiliations.
Ready to submit your research? Choose BMC and benefit from:

- fast, convenient online submission

- thorough peer review by experienced researchers in your field

- rapid publication on acceptance

- support for research data, including large and complex data types

- gold Open Access which fosters wider collaboration and increased citations

- maximum visibility for your research: over $100 \mathrm{M}$ website views per year

At BMC, research is always in progress.

Learn more biomedcentral.com/submissions 